\title{
Intrauterine Growth Retardation: Fetal Glucose Transport is Diminished in Lung but Spared in Brain
}

\author{
REBECCA A. SIMMONS, ANNETTE S. GOUNIS, SHRIKAR A. BANGALORE, AND \\ EDWARD S. OGATA
}

Division of Neonatology, Departments of Pediatrics, Obstetrics, and Gynecology, Northwestern University Medical School and Children's Memorial Hospital, Chicago, Illinois 60614

\begin{abstract}
Uteroplacental insufficiency" often causes asymmetric fetal growth retardation. Glucose transporters control cell glucose utilization and thus may be critical in the control of fetal growth. We hypothesized that uteroplacental insufficiency might alter glucose transporter activity, protein, and gene expression and thereby affect discordant organ growth in small-for-gestational-age (SGA) fetuses. We performed bilateral uterine artery ligation in pregnant rats on d 19 of gestation (term-21.5 d) to cause uteroplacental insufficiency and obtained fetal brain and lung tissue on $d 20$. The brain mass of SGA fetuses did not differ from that of sham and normal fetuses, but lung mass was significantly diminished. Glucose transport, measured with $\left[{ }^{3} \mathrm{H}\right] 2$-deoxyglucose, was similar in glial cells and brain tissue of SGA, sham, and normal fetuses. In contrast, type II pneumocytes, lung fibroblasts, and lung tissue of SGA fetuses had significantly decreased glucose transport. The intrinsic activity of the glucose transporter $(\mathrm{Km})$ was not altered in the brain or lung of SGA fetuses. Total glucose transporter protein measured by cytochalasin-B binding and glucose transporter $1 \mathrm{mRNA}$ was diminished in SGA lung tissue and type II pneumocytes, but not in SGA brain tissue or glial cells. We could not detect glucose transporter 3 mRNA in significant quantity in any tissue. With uteroplacental insufficiency, glucose transport is differentially altered in lung and brain. Glucose transporter protein and gene expression are diminished in the lung and normal in the brain of SGA fetuses. These changes may contribute to fetal growth retardation and the phenomenon of "brain sparing." (Pediatr Res 31: 59-63, 1992)
\end{abstract}

\section{Abbreviations}

SGA, small for gestational age

2-DG, 2-deoxyglucose

When "uteroplacental insufficiency" complicates a pregnancy, asymmetric fetal growth retardation develops. Under such conditions, overall somatic growth is retarded but gross brain growth remains normal. The mechanisms responsible for the phenomenon of "brain sparing" are not well understood.

Received December 7, 1990; accepted August 8, 1991.

Correspondence and reprint requests: Rebecca A. Simmons, M.D., Department of Pediatrics, Children's Memorial Hospital, Division of Neonatology, Box 45 , 2300 Children's Plaza, Chicago, IL 60614.

Supported in part by NIH I PO1 19070, the Juvenile Diabetes Foundation, and the Children's Memorial Institute for Education and Research.
In previous studies we quantitated factors responsible for fetal growth retardation by performing bilateral uterine artery ligation in the maternal rat (1). This technique, an extreme example of uteroplacental insufficiency, restricts glucose and amino acid availability and alters a number of physiologic variables in the fetus including gaseous exchange (2). Glucose is one of several important metabolic fuels for the fetus, and limitation of its availability and utilization is probably involved in retarding fetal growth.

In most fetal tissues, glucose uptake is controlled by a facilitated transport mechanism. Glucose transporters are a family of structurally related proteins encoded by distinct genes and expressed in a tissue-specific manner (3-5). cDNA encoding a glucose transporter have been cloned from both rat brain and human hepatoma (Hep G2) cell libraries $(6,7)$. This glucose transporter has been termed Glut 1 and is present in most fetal tissues including brain $(8,9)$. Glut 3 , originally cloned from human fetal skeletal muscle, has been found in small quantities in fetal rabbit brain (9).

How uteroplacental insufficiency affects glucose transport in the fetus and thereby contributes to the development of growth retardation is unknown. Several in vivo studies using 2-deoxyglucose in the pregnant rat have demonstrated limited glucose transfer to the fetus after maternal uterine artery ligation $(10$, 11).

When substrate supply is limited to the fetus, tissue-specific regulation of glucose transporters might ration glucose availability to organs. In this manner, glucose transport and glucous transporter gene expression might differ between brain and other tissues, and this might in part be responsible for brain sparing in the SGA fetus. To address this possibility, we measured glucose transporter activity, total glucose transporter protein, and glucose transporter mRNA in freshly isolated brain and lung tissue and in cultured cell monolayers of brain and lung from SGA and normal rat fetuses. Glial cells, type II pneumocytes, and lung fibroblasts represent major cellular components of brain and lung and have important metabolic functions. We compared brain to lung because in the SGA fetal rat the brain has high metabolic activity and growth sparing, whereas the lung is less metabolically active and has decreased growth.

We found that glucose transporter activity, protein, and mRNA do not differ in the brain of SGA and normal fetuses. In contrast, lungs of SGA fetuses have significantly diminished glucose transport. These data suggest that under conditions of uteroplacental insufficiency, glucose transport and glucose transporter gene expression are differentially altered in the brain and lung. These changes along with other factors contribute to the development of intrauterine growth retardation and may in part be responsible for brain sparing. 


\section{MATERIALS AND METHODS}

Animals. We have described our surgical methods previously (1). In brief, time-dated, pregnant Sprague-Dawley rats were individually housed under standard conditions and allowed free access to standard rat food and water. On d 19 of gestation, the maternal rats were anesthetized with intraperitoneal Xylazine (Rompun Mobay Co., Shawnee, KS; $8 \mathrm{mg} / \mathrm{kg}$ ) and ketamine (40 $\mathrm{mg} / \mathrm{kg}$ ), and both uterine arteries were ligated (SGA). We had two control groups: sham animals who underwent the identical anesthetic and surgical procedure except for ligation (sham), and animals who did not undergo any surgical procedure (normals). Rats recovered within a few hours and had ad libitum access to food and water. On d 20 the mothers were killed by cervical dislocation, the fetuses were immediately delivered and decapitated, and organs were quickly harvested. Litters from 21 maternal rats who underwent bilateral uterine artery ligation (SGA), 12 who underwent sham surgery (sham), and 19 who had no anesthesia or surgery (normals) were used for these studies.

Culture and isolation of glial cells, type II pneumocytes, and lung fibroblasts. The brains were removed under sterile conditions and dissociated with $0.25 \%$ trypsin and DNase $(10 \mu \mathrm{g} / \mathrm{mL})$ $(12,13)$. The cells were plated on poly-L-lysine coated plates and maintained at $37^{\circ} \mathrm{C}$ in a humidified atmosphere of $95 \%$ air and $5 \% \mathrm{CO}_{2}$. At $72 \mathrm{~h}$, the plates were washed, and the resultant adherent cells were trypsinized, replated, and grown in Dulbecco's modified Eagle's medium with $10 \%$ FCS. The cells were incubated for $6 \mathrm{~d}$ in Dulbecco's modified Eagle's medium supplemented with $10 \%$ FCS before use in glucose transport experiments. Media was changed every 1-2 d. Determinations of purity of glial cell cultures by staining with glial fibrillary protein $(95 \%)$ were made just before their use in experiments.

Lungs were removed and dissected under sterile conditions. The trachea and major airways were removed, and the remaining tissue was chopped into $1-\mathrm{mm}^{3}$ cubes. Tissue from an entire litter was pooled. Explants were cultured for $24 \mathrm{~h}$ in serum-free Waymouth's media ( $2 \mathrm{~mL} / \mathrm{dish})$ at $37^{\circ} \mathrm{C}$ in a humidified atmosphere of $95 \%$ air and $5 \% \mathrm{CO}_{2}(10)$. The tissue was harvested, and a cell suspension was made by incubating the tissue with a trypsinizing solution $(14,15)$. A differential adherence method was used for separating type II pneumocytes from fibroblasts (14, $15)$. After $48 \mathrm{~h}$ culture in minimal essential medium supplemented with $10 \%$ FCS, the plates were rinsed with PBS and the confluent monolayers of pneumocytes were used for transport experiments. Hematoxylin- $\mathrm{LiCO}_{3}$ staining was used to confirm purity (at least $90 \%$ pure) of the type II pneumocytes just before their use in experiments. Lung fibroblasts were grown in minimal essential medium supplemented with $10 \%$ FCS for 5-7 d before use in transport experiments. Media was changed daily in the type II pneumocyte and fibroblast cultures.

Membrane preparation. Membranes were prepared from uncultured brain and lung tissue and glial cells, type II pneumocytes, and lung fibroblasts. Brains and lungs were dissected from fetal rats and extensively washed to remove red blood cells. Tissues and cell monolayers were washed, placed in ice-cold isolation buffer ( $250 \mathrm{mM}$ sucrose, $2 \mathrm{mM}$ EDTA, $10 \mathrm{mM}$ Tris$\mathrm{HCl}, 1.5 \mathrm{mM}$ phenylmethylsulfonylfluoride, $25 \mathrm{mM}$ benzamidine, $2 \mu \mathrm{M}$ leupeptin, $2 \mu \mathrm{M}$ pepstatin, and 500 kallikrein inhibitor units/mL aprotinin), and homogenized with a small Polytron probe for $6 \mathrm{~s}$ (tissue) or a Virtis (Virtis Co., Gardiner, NY) sonicator (cell monolayers). The homogenates were centrifuged at $5000 \times g$ for $5 \mathrm{~min}$ at $4^{\circ} \mathrm{C}$, and the supernatant was centrifuged at $100000 \times g$ for $90 \mathrm{~min}$ at $4^{\circ} \mathrm{C}$. The pellet was suspended in cold isolation buffer by several passes through a 22-gauge needle. Protein was determined by the method of Lowry (15).

Glucose transport. 2-DG transport studies were performed in fresh brain and lung tissue, cultured glial cells, type II pneumocytes, and lung fibroblasts from SGA, sham, and normal fetal rats on $\mathrm{d} 20$ of gestation. These methods have been described previously (16). Cultured monolayers of type II pneumocytes, lung fibroblasts, and glial cells, were washed with $10 \mathrm{~mL}$ of $37^{\circ} \mathrm{C}$ PBS. Glucose transport was initiated by adding $\left[{ }^{3} \mathrm{H}\right] 2-\mathrm{DG}$ to the incubation media [incubation media: $900 \mu \mathrm{L}$ PBS, $100 \mu \mathrm{L}\left[{ }^{3} \mathrm{H}\right]$ 2-DG $(0.16 \mathrm{mM}, 1 \mu \mathrm{Ci} / \mathrm{mL})]$. 2-DG, a glucose analog, enters the cell and is phosphorylated but not further metabolized. Thus, the uptake of 2-DG into cells reflects both transport and phosphorylation of glucose. Transport rather than phosphorylation has been determined to be the rate-limiting step of 2-DG uptake in brain and lung $(17,18)$. Therefore, determination of 2-DG uptake into brain and lung cells is a valid measurement of glucose transport. Cells were incubated for different periods $(0,0.5,1,5$, 10,15 , and $20 \mathrm{~min}$ ). At the end of each period, transport was stopped by the addition of ice-cold PBS. Cells were washed and solubilized with $1 \%$ Triton. An aliquot from this was used for determination of radioactivity and for determination of DNA. Noncarrier-mediated transport was determined by adding $10 \mu \mathrm{M}$ cytochalasin B (maximal inhibitory concentration in all three cell types), a fungal metabolite that is a specific and competitive inhibitor of glucose transport, to the incubation media. 2-DG uptake was then determined. The final concentration of ethanol in the solution was less than $1 \%$. Nonspecific binding of glucose was determined by adding 1000 -fold excess of unlabeled 2-DG to the incubation media. Nonspecific binding and noncarriermediated transport were subtracted to determine specific transport. The addition of cytochalasin B to the cell cultures inhibited transport of $2-D G$ by $85 \%$ in the brain cells, $65 \%$ in the type II pneumocytes, and $90 \%$ in lung fibroblasts. To determine the kinetics of glucose transport, the cell monolayers were incubated with $0.5,1,2,5,10$, and $20 \mathrm{mM} 2-\mathrm{DG}$, and glucose transport was determined as described above.

For glucose transport experiments done in uncultured tissue, brains and lungs were chopped and $100 \mathrm{mg}$ of tissue were placed in 35-mL sterile plastic tubes and centrifuged for $5 \mathrm{~min}$. Glucose transport was determined at $0,10,20,40$, and $60 \mathrm{~min}(n=7$ experiments). We used $\left[{ }^{3} \mathrm{H}\right]$ inulin to determine extracellular water space.

Transport was related to DNA and protein content. DNA content was determined by fluorometric assay (19).

$C y$ tochalasin-B binding. We used cytochalasin-B binding studies to quantitate glucose transporter protein $(20-22)$ in membranes of brain and lung tissue and cultured cells from SGA, sham, and normal fetuses. The assay was a modification of the procedure of Cushman and Wardzala (23). Brain and lung membranes $(10 \mathrm{mg} / \mu \mathrm{L})$ were mixed with $200 \mu \mathrm{L}$ of $1 \% \mathrm{NaCl}$ and $100 \mu \mathrm{L}$ of $20 \mu \mathrm{M}$ cytochalasin $\mathrm{E}$ in $1 \% \mathrm{NaCl}$. Aliquots (75 $\mu \mathrm{L})$ were withdrawn and added to $40 \mu \mathrm{L}$ of $2 \mathrm{M}$ D-glucose or Lglucose and $20 \mu \mathrm{L}\left[{ }^{3} \mathrm{H}\right]$ cytochalasin B (DuPont-New England Nuclear, Boston, MA; $13.5 \mathrm{Ci} / \mathrm{mmol}$ ). After incubation at room temperature for $15 \mathrm{~min}$, the suspension was centrifuged at $100000 \times g$ for $1 \mathrm{~h}$ at $4^{\circ} \mathrm{C}$. Aliquots of clear supernatant were withdrawn to determine the free concentration of cytochalasin B. The pellet was solubilized in $5 \mathrm{~mL}$ of scintillation fluid (Cytoscint; ICN, Plainview, NY) and counted. $\left[{ }^{14} \mathrm{C}\right]$ mannitol $(64$ $\mu \mathrm{M} ; 52.0 \mathrm{mCi} / \mathrm{mmol}$ ) was also included to correct for nonspecific binding of $\left[{ }^{3} \mathrm{H}\right]$ cytochalasin $\mathrm{B}$.

Northern and slot-blot analysis. Total RNA was extracted using RNazol (guanidinium thiocyanate, phenol, 2-mercaptoethanol; Cinna/Biotecx, Friendswood, TX). RNA $(10 \mu \mathrm{g})$ was fractionated by $1.2 \%$ agarose- $6.6 \%$ formaldehyde gels and transferred to Nytran filters (Schleicher \& Schell, Keene, NH) (24). The gel was stained with ethidium bromide and visualized under UV light. RNA was fixed to the filter by baking for $2 \mathrm{~h}$ at $180^{\circ} \mathrm{C}$. The filters were prehybridized for $3 \mathrm{~h}$ at $42^{\circ} \mathrm{C}$ in $50 \%$ formamide, $5 \times \operatorname{SSC}\left(3 \mathrm{M} \mathrm{NaCl}, 3 \mathrm{M} \mathrm{Na}_{3}\right.$ citrate $\left.\cdot 2 \mathrm{H}_{2} \mathrm{O}\right), 1 \%$ glycine, $5 \times$ Denhardt's solution $(0.02 \%$ each of Ficoll 400 , polyvinylpyrrolidone, and BSA), $100 \mu \mathrm{g}$ of herring sperm DNA, and $100 \mu \mathrm{g}$ torula yeast RNA. A full-length $2.8-\mathrm{kb}$ rat brain D-glucose transporter cDNA (Glut 1) in the plasmid pGEM and the 493-bp Glut 3 cDNA (cloned from mouse) (both kindly provided by $G$. Bell) were labeled with ${ }^{32} \mathrm{P}$ dCTP (Amersham, Arlington Heights, 
IL) with random oligonucleotide primers (Pharmacia Oligo Labeling Kit; Pharmacia, Inc., Piscataway, NJ). The filters were hybridized with $1 \times 10^{6} \mathrm{cpm} / \mathrm{mL}$ of the labeled probe at $42^{\circ} \mathrm{C}$ overnight. After hybridization, the filters were washed twice for 5 min at $23^{\circ} \mathrm{C}$ in $5 \times \operatorname{SSPE}$ (sodium chloride, sodium phosphate, EDTA), $0.1 \% \mathrm{SDS}$, and 3 times for $30 \mathrm{~min}$ at $50^{\circ} \mathrm{C}$ with $0.1 \times$ SSPE, $0.1 \%$ SDS. Autoradiography was done using Kodak XAR5 film and two intensifying screens for $48 \mathrm{~h}$ at $-70^{\circ} \mathrm{C}$. In addition, slot blots with $10 \mu \mathrm{g}$ total RNA were performed to determine mRNA abundance results. The relative amount of Glut $1 \mathrm{mRNA}$ was quantitated by densitometry. The membranes were stripped and rehybridized to human B-actin CDNA as a control.

Statistical analyses were performed using analysis of variance and the $t$ test (25). Data are reported as means \pm SEM. These studies were approved by the Institutional Animal Care and Use Committee of Children's Memorial Institute for Education and Research.

\section{RESULTS}

The body mass of SGA fetuses, $2.96 \pm 0.11 \mathrm{~g}$, was significantly less than that of sham $(3.16 \pm 0.10 \mathrm{~g})$ and normal $(3.86 \pm 0.08$ g) fetuses. The body weight of sham fetuses was intermediate and differed significantly from SGA and normal fetuses. The brain mass of SGA fetuses $(112.1 \pm 11.0 \mathrm{mg})$ did not differ from that of sham $(125 \pm 15 \mathrm{mg})$ and normal $(127.5 \pm 23.2 \mathrm{mg})$ fetuses. However, the lungs from SGA fetuses were significantly lighter than those of sham and normal fetuses (SGA 96.6 \pm 11.0 , sham $119.4 \pm 15.6$, normal $134.5 \pm 23.7 \mathrm{mg}, p<0.05)$. Lung mass was similar in sham and normal fetuses.

Total protein and DNA content did not differ significantly among SGA, sham, and glial cells, type II pneumocytes, and lung fibroblasts.

Transport of 2-DG in glial cells was linear at $37^{\circ} \mathrm{C}$ for at least $15 \mathrm{~min}$ and then reached saturation by $20 \mathrm{~min}$ (Fig. 1). 2-DG transport in SGA glial cells was similar to sham and normal values. Similarly, there was no difference in $2-D G$ transport in freshly isolated brain. By $60 \mathrm{~min}$ of incubation with 2-DG, glucose transport reached a plateau and was similar in SGA, sham, and normal brain tissue.

Neither the $V_{\max }$ nor the $\mathrm{Km}$ of glial cells differed among SGA, sham, and normal fetuses (Table 1). Therefore, the rate of 2-DG transport and its affinity for the glucose transporter are similar in SGA, sham, and normal glial cells.

The total amount of glucose transporter protein in whole brain and glial cell membranes, as measured by $\left[{ }^{3} \mathrm{H}\right]$ cytochalasin- $\mathrm{B}$ binding, did not significantly differ between SGA (glial cells $0.290 \pm 0.079$, brain tissue $0.569 \pm 0.573 \mathrm{pM} / \mu \mathrm{g}$ DNA) and normal (glial cells $0.292 \pm 0.092$, brain tissue $0.573 \pm 0.113 \mathrm{pM}$ / $\mu \mathrm{g}$ DNA) fetal rats.

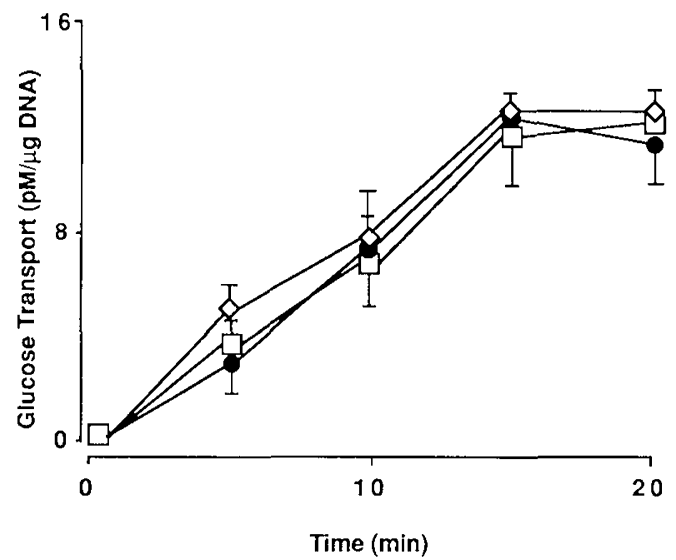

Fig. 1. 2-DG transport ( $n=7$ experiments) in glial cells from SGA $(\bullet)$, sham $(\diamond)$, and normal $(\square)$ fetal rats on d 20 of gestation. No differences were noted among the three groups.
Table 1. Kinetics of 2-DG transport in glial cells, type II pneumocytes, and lung fibroblasts of SGA, sham, and normal fetal rats*

\begin{tabular}{lcc}
\hline & $\begin{array}{c}\mathrm{V}_{\max } \\
(\mathrm{pM} / \mu \mathrm{g} \text { DNA })\end{array}$ & $\begin{array}{c}\mathrm{Km} \\
(\mathrm{mM})\end{array}$ \\
\hline Glial cells & & \\
SGA & $7.52 \pm 1.23$ & $2.08 \pm 0.65$ \\
Sham & $8.25 \pm 2.09$ & $2.19 \pm 0.76$ \\
$\quad$ Normal & $8.85 \pm 1.12$ & $1.92 \pm 0.45$ \\
Type II pneumocytes & & \\
$\quad$ SGA & $2.80 \pm 0.87 \dagger$ & $2.09 \pm 0.54$ \\
Sham & $4.23 \pm 0.75$ & $1.95 \pm 0.87$ \\
$\quad$ Normal & $4.31 \pm 1.01$ & $2.15 \pm 0.66$ \\
Lung fibroblasts & & \\
$\quad$ SGA & $3.10 \pm 0.99 \dagger$ & $2.98 \pm 0.75$ \\
$\quad$ Sham & $10.96 \pm 3.46$ & $3.01 \pm 1.01$ \\
$\quad$ Normal & $12.06 \pm 2.35$ & $2.54 \pm 0.67$ \\
\hline
\end{tabular}

$* \mathrm{~V}_{\max }$ and $\mathrm{Km}$ were calculated using Lineweaver-Burk plots.

$\dagger p<0.05$ compared to corresponding values for sham and normal fetuses.

Northern and slot-blot analysis demonstrated that the amount of the 2.8-kb glucose transporter mRNA, Glut 1, was similar in uncultured brain tissue and cultured glial cells from SGA and normal fetuses (Figs. 2 and 3). A very weak Glut 3 mRNA signal was detected in cultured glial cells and uncultured brain tissue.

In contrast to the brain, lung 2-DG uptake was significantly diminished in SGA compared to sham and normal fetuses. Transport of 2-DG was linear up to $10 \mathrm{~min}$ in type II pneumocytes (Fig. 4) and lung fibroblasts. Of note, 2-DG uptake was inhibited only $65 \%$ by $10 \mu \mathrm{M}$ cytochalasin B. Because cytochalasin B only inhibits facilitated glucose transport, it is likely that approximately $35 \%$ of $2-\mathrm{DG}$ uptake is via $\mathrm{Na}^{+}$-coupled glucose transport. $\mathrm{Na}^{+}$-coupled glucose transport has been shown to occur in the lung and may account for a substantial proportion of glucose uptake by type II pneumocytes (26). 2-DG uptake was also significantly diminished in uncultured lung tissue from SGA fetuses, averaging $0.297 \mathrm{pM} / \mathrm{min} / \mu \mathrm{g}$ DNA compared to 1.126 $\mathrm{pM} / \mathrm{min} / \mu \mathrm{g}$ DNA for shams and $1.524 \mathrm{pM} / \mathrm{min} / \mu \mathrm{g}$ DNA for normals $(p<0.05)$.

SGA type II pneumocytes demonstrated a significantly lower $\mathrm{V}_{\max }$ than shams and normals. The difference in $\mathrm{V}_{\max }$ among SGA, shams, and normals was even greater in lung fibroblasts. $\mathrm{V}_{\max }$ was four times less in SGA compared to normal fibroblasts. However, the $\mathrm{Km}$ values for type II pneumocytes and lung fibroblasts were similar in all three groups (Table 1).

$\left[{ }^{3} \mathrm{H}\right]$ cytochalasin-B binding was also significantly diminished in SGA fetal whole lung $(0.044 \pm 0.028 \mathrm{pM} / \mu \mathrm{g}$ DNA $)$ and type II pneumocyte membranes $(0.030 \pm 0.011 \mathrm{pM} / \mu \mathrm{g}$ DNA) compared to normal fetuses (lung tissue $0.098 \pm 0.031 \mathrm{pM} / \mu \mathrm{g}$ DNA, type II pneumocytes $0.058 \pm 0.013 \mathrm{pM} / \mu \mathrm{g}$ DNA; $p<0.05$ ).

Glut 1 was abundantly expressed in lung tissue, type II pneumocytes, and lung fibroblasts from SGA, sham, and normal fetuses. Northern and slot-blot analyses demonstrated that compared to normals, Glut $1 \mathrm{mRNA}$ was diminished by approximately $50 \%(p<0.05)$ in uncultured lung tissue and cultured type II pneumocytes of SGA fetuses (Figs. 2 and 3). There was a 3 -fold decline in Glut $1 \mathrm{mRNA}$ abundance in lung fibroblasts. We were unable to detect Glut $3 \mathrm{mRNA}$ signal in type II pneumocytes or uncultured lung tissue from SGA, sham, or normal fetuses.

To ensure that the decrease in Glut 1 mRNA in SGA fetal lungs was specific for the D-Glut mRNA, the samples were probed with the cDNA B-actin. There were no differences in Bactin mRNA between SGA, sham, and normal fetuses (data not shown).

\section{DISCUSSION}

Diminished somatic growth with normal brain growth is characteristic of intrauterine growth retardation caused by uteropla- 


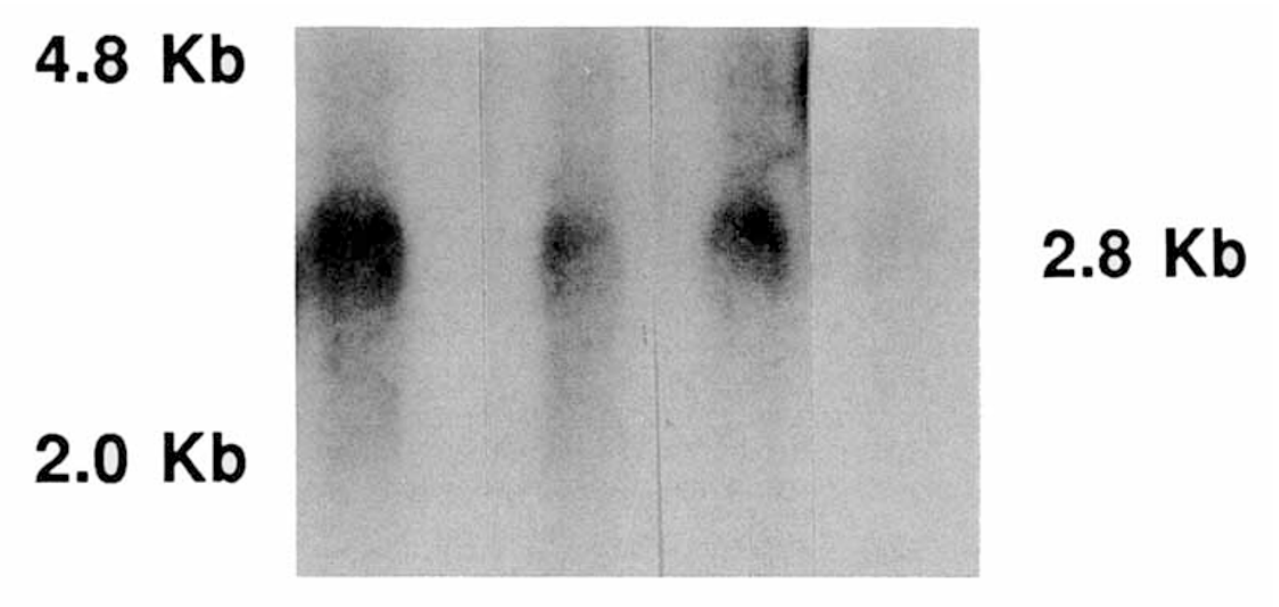

Brain

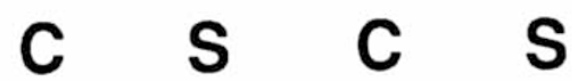

Fig. 2. Northern blot analyses of brain and lung tissue total RNA. An autoradiograph of a Northern blot probed with Glut 1 cDNA. There was no difference in intensity of bands between SGA $(S)$ and normal $(C)$ fetal brain tissue. In contrast, Glut 1 signal intensity in SGA lung tissue was significantly diminished.

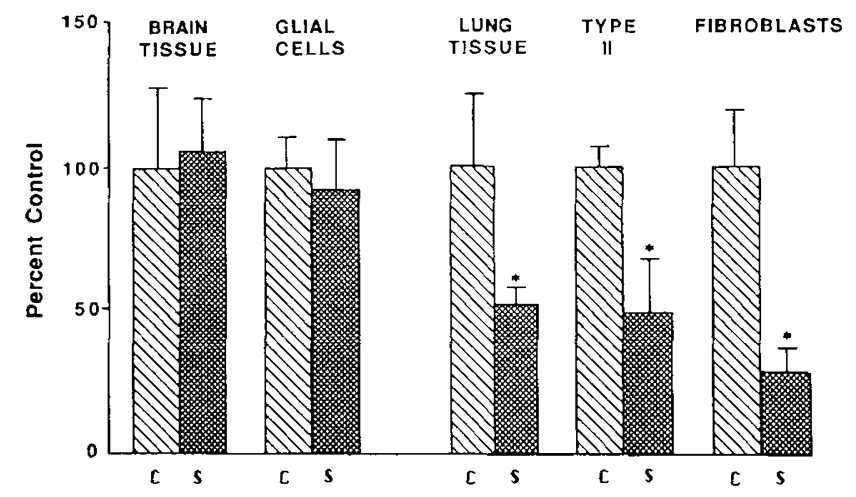

Fig. 3. Densitometry of slot blots probed with Glut 1. Each bar represents the mean \pm SEM of four experiments. Data for SGA $(S)$ were related to normal $(C)$ values normalized as $100 \%$. Glut 1 mRNA levels were similar in SGA and normal fetal brain tissue and giial cells. In contrast, Glut $1 \mathrm{mRNA}$ levels were significantly diminished in SGA lung tissue type II pneumocytes and lung fibroblasts. ${ }^{*}, p<0.05$.

cental insufficiency and other maternal disorders during pregnancy. The mechanisms at the cellular level responsible for impairing somatic growth but sparing brain growth are poorly understood. Because glucose is an important metabolic fuel for the fetus, we reasoned that glucose transport might be related to these phenomena. Our study demonstrates that glucose transporter activity, protein, and gene expression are normal in SGA fetal brain and diminished in lung under conditions mimicking uteroplacental insufficiency. Because glucose provision is important for cell metabolism and growth, these observations indicate a link between differences in tissue glucose transport and the asymmetric organ growth in intrauterine growth retardation.

We and others have found brain growth to be normal in SGA rat fetuses $(1,27)$. This study indicates that total glucose transporter activity, protein, and Glut 1 expression are also normal in the SGA fetal rat brain. Brain tissue and glial cell 2-DG uptake, cytochalasin-B binding, and Glut 1 mRNA did not differ between SGA, sham, and normal fetuses. These observations indicate that the numerous metabolic and physiologic variables

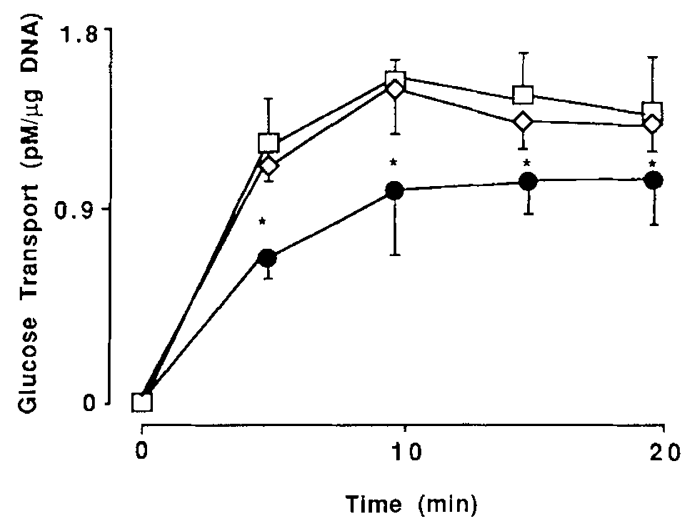

Fig. 4. 2-DG transport in type II pneumocytes from SGA (•), sham $(\diamond)$, and normal $(\square)$ fetal rats on d 20 of gestation ( $n=7$ experiments). Type II pneumocytes from SGA fetuses had significantly diminished transport at each point. ${ }^{*}, p<0.05$.

altered by maternal uterine artery ligation do not alter fetal brain glucose transport.

The mechanisms responsible for normal glucose transporter activity, protein, and expression in the brain of SGA fetuses are unknown. Glucose transport might have been maintained as a result of sustained glucose availability. With maternal uterine artery ligation, glucose provision to the fetus is compromised; however, blood flow to the brain may be increased relative to other organs (28). This may maintain provision of glucose to the brain and guarantee normal brain glucose transport and growth.

We found that maternal uterine artery ligation reduces both glucose transporter activity, protein, and mRNA in fetal lung, an organ in which growth is retarded. This technique results in transient decreases in fetal glucose and amino acid concentrations and altered gaseous exchange to the fetus. Cellular energy and redox states are transiently altered (29), and plasma insulin and IGF concentrations are diminished $(1,2,30,31)$. The combination of these altered variables could affect glucose transport by tissue-specific regulation of glucose transporter gene expression, i.e. reducing lung but maintaining brain glucose 
transport. It should also be pointed out that cell glucose transport might not actually modulate fetal growth but merely reflect intrinsic growth. The alterations in physical factors resulting from uteroplacental insufficiency could modulate tissue metabolism, which in turn could reduce glucose transport.

How the alterations in fetal metabolism resulting from maternal uterine artery ligation affect fetal glucose transport is unclear. In the adult rat, limited glucose availability resulting from fasting decreases glucose transport in adipose tissue $(32,33)$. Diminished insulin availability caused by streptozotocin treatment or fasting decreases adult rat muscle glucose transport (34-36). Acidosis can impair glucose transporter function and produce insulin resistance $(32,34)$. Little is known about the effects of these alterations on fetal glucose transporters.

Diminished glucose uptake in the SGA fetal lung could result from decreased Glut 1 gene expression or altered glucose transporter protein. We found that total glucose transporter protein as measured by cytochalasin-B binding and Glut 1 mRNA were similarly decreased in type II pneumocytes and lung fibroblasts of SGA, sham, and normal fetuses. However, the affinity of glucose transporters for glucose did not differ between SGA and normal lung. Therefore, the metabolic and physiologic variables altered in the SGA fetus appear to act at the transcriptional or posttranscriptional (altered mRNA stability) level rather than at the posttranslational level in lung.

Isoforms other than Glut 1 could contribute to fetal glucose uptake. Glut 3 has been found in small amounts in fetal and newborn rabbit brain (8). Our data suggest that little Glut 3 (as measured by the mouse cDNA probe) is expressed in the fetal rat brain and even less is expressed in lung.

In vitro conditions could have affected measurements of cell glucose transport. We performed 2-DG studies in type II pneumocytes after $3 \mathrm{~d}$ and in glial cells after $7 \mathrm{~d}$ of culture. This difference was unavoidable because type II pneumocytes dedifferentiate with longer incubation. In contrast, the sufficient growth of glial cell monolayers requires at least $7 \mathrm{~d}$, and dedifferentiation does not occur. Glucose transport was similar in SGA and normal uncultured brain tissue and in cultured glial cells. Glucose transport, cytochalasin-B binding and Glut 1 expression were similarly diminished in uncultured lung tissue and in cultured type II pneumocytes and lung fibroblasts from SGA fetuses. These similarities confirm that the in vitro conditions for cell monolayer culture did not alter the in vivo effects of maternal uterine artery ligation upon fetal brain and lung glucose transport.

These data suggest that under conditions of uteroplacental insufficiency, which results in numerous metabolic and physiologic alterations in the SGA fetus, glucose transport is differentially altered in the brain and lung. To the extent that glucose is an important metabolic fuel for the fetus, this limitation of glucose transport may affect the growth of such organs as the lung. The maintenance of glucose transport in the brain may be one mechanism to assure normal brain growth and may contribute to the brain sparing phenomenon seen in SGA fetuses.

\section{REFERENCES}

1. Ogata ES, Bussey M, LaBarbera A, Finley S 1985 Altered growth, hypoglycemia, hypoalanemia, and ketonuria in the young rat: postnatal consequences of intrauterine growth retardation. Pediatr Res 19:32-37

2. Ogata ES, Bussey M, Finley S 1986 Altered gas exchange, limited glucose, branched chain amino acids, and hyperinsulinism retard fetal growth in the rat. Metabolism 35:950-977

3. James DE, Strube M, Mueckler M 1989 Molecular cloning and characterization of an insulin-regulatable glucose transporter. Nature 338:83-87

4. Fukumoto H, Serino S, Imura H, Seino Y, Eddy RL, Fukishima Y, Byers MG, Shows TB, Bell GI 1988 Sequence, tissue distribution, and chromosomal localization of mRNA encoding a human glucose transporter-like protein. Proc Natl Acad Sci USA 85:5434-5438

5. Kayano T, Fukomoto H, Eddy RL, Fan YS, Byers MG, Shows TB, Bell GI
1988 Evidence for a family of human glucose transporter-like proteins: sequence and gene localization of a protein expressed in fetal skeletal muscle and other tissues. J Biol Chem 263:15245-15248

6. Mueckler MM, Caruso C, Baldwin SA, Panico M, Blench I, Morris HR, Allard WJ, Lienhard GE, Lodish HF 1985 Sequence and structure of a human glucose transporter. Science 229:941-945

7. Birnbaum MJ, Haspel HC, Rosen OM 1986 Cloning and characterization of cDNA encoding the rat brain glucose-transporter protein. Proc Natl Acad Sci USA 83:5784-5788

8. Sadiq F, Holtzclaw L, Shundu K, Muzzafar A, Kevaskar S 1990 The ontogeny of the rabbit brain glucose transporter. Endocrinology 126:2417-2424

9. Sivitz W, DeSautel S, Walker PS, Pessin JE 1989 Regulation of the glucose transporter in developing rat brain. Endocrinology 124:1875-1880

10. Lueder F, Ogata ES 1990 Uterine artery ligation in the maternal rat alters fetal tissue glucose utilization. Pediatr Res 28:464-468

11. Nitzan M, Orloff S, Schulman JD 1979 Placental transfer of analogs of glucose and amino acids in experimental growth retardation. Pediatr Res 13:100 103

12. Clarke DW, Boyd FT, Kappy MS, Raizada MK 1984 Insulin binds to specific receptors and stimulates 2-deoxy-D-glucose uptake in cultured glial cells from rat brain. J Biol Chem 259:11672-11675

13. Raizada MK. Muther TI, Summers C 1984 Increased angiotensin II specific receptors in neuronal cultures of hypertensive rat brain. Am J Physiol 247:C364-C369

14. Gross I, Smith GJW, Maniscalco WM, Czajka MR, Wilson CM, Rooney SA 1978 An organ culture model for study of biochemical development of fetal rat lung. J Appl Physiol 45:355-362

15. Batenburg JJ, Otto-Verberne CJM, Ten Have-Opbroek A, Klazinga W 1988 Isolation of alveolar type II cells from fetal rat lung by differential adherence in monolayer culture. Biochim Biophys Acta 960:441-453

16. Klip A, Ramial T 1987 Cytoplasmic $\mathrm{Ca}^{2+}$ during differentiation of 3T3-Cl adipocytes. J Biol Chem 262:9141-9146

17. Widdas WF 1988 Old and new concepts of the membrane transport for glucose in cells. Biochim Biophys Acta 947:385-404

18. Perez-Diaz J, Martin-Reguero A, Ayuso-Parrilla M, Parrilla R 1977 Metabolic features of isolated rat lung cells. I. Factors controlling glucose utilization. Am J Physiol 232:E394-E400

19. Setaro F, Morley C 1976 A modified fluorometric method for determination of microgram quantities of DNA from cell or tissue cultures. Anal Biochem 71:313-317

20. Wardzala LJ, Cushman SW, Salans LB 1978 Mechanism of insulin action on glucose transport in the isolated rat adipose cell. J Biol Chem 253:80028005

21. Hara M, Matsuda Y, Nakagawa H 1987 Molecular characteristics of rat brain glucose transporter: a novel species with $\mathrm{Mr} 45,000$. J Biochem (Tokyo) 101:43-52

22. Wang C 1987 The D-glucose transporter is tissue specific. J Biol Chem 262:15689-15693

23. Cushman SW, Wardzala LJ 1980 Potential mechanism of insulin action on glucose transport in the isolated rat adipose cell. J Biol Chem 255:4758 4762

24. Maniatis T, Fritsch EF, Sambrook J 1989 Molecular Cloning, A Laboratory Manual. Cold Spring Harbor Laboratory Press, Cold Spring Harbor, NY

25. Zar JH 1984 Biostatistical Analysis. Prentice-Hall, Englewood Cliffs, NJ

26. Basset G, Saumon G, Bouchonnet F, Crone C 1988 Apical sodium-sugar transport in pulmonary epithelium in situ. Biochim Biophys Acta 92:11-18

27. Greenwald R 1963 Chronic fetal distress and placental insufficiency. Biol Neonate 5:215-219

28. Veille JC, Cohen I 1990 Middle cerebral artery blood flow in normal and growth-retarded fetuses. Am J Obstet Cynecol 162:391-396

29. Ogata ES, Swanson SL, Collins JW, Finley SL 1990 Intrauterine growth retardation: altered hepatic energy and redox states in the fetal rat. Pediatr Res 27:56-63

30. Vileisis RA, D'Ercole AJ 1986 Tissue and serum concentrations and somatomedin-C/insulin-like growth factor $I$ in fetal rats made growth retarded by uterine artery ligation. Pediatr Res 20:126-130

31. Davenport ML, D'Ercole AJ, Underwood LE 1990 Effect of maternal fasting on fetal growth, serum insulin-like growth factors (IGFs), and tissue IGF messenger ribonucleic acids. Endocrinology 126:2062-2067

32. Charron MJ, Kahn BB 1990 Divergent molecular mechanisms for insulin resistant glucose transport in muscle and adipose cells in vivo. J Biol Chem 265:7994-8000

33. Berger J, Biswas C, Vicario PP, Strout HV, Saperstein R, Pilch PF 1989 Decreased expression of the insulin-responsive glucose transporter in diabetes and fasting. Nature 340:70-74

34. LeMarchand-Brustel Y, Freychet P 1979 Effect of fasting and streptozotocin diabetes on insulin binding and action in the isolated mouse soleus muscle. $\mathrm{J}$ Clin Invest 64:1505-1515

35. Thorens B, Flier JS, Lodish HF, Kahn BB 1990 Differential regulation of two glucose transporters in rat liver by fasting and refeeding and by diabetes and insulin treatment. Diabetes 39:712-719

36. Kahn B, Sharron M, Lodish H, Cushman S, Flier J 1989 Differential regulation of two glucose transporters in adipose cells from diabetic and insulin-treated diabetic rats. $\mathrm{J}$ Clin Invest 84:404-411 